collagen, and this is supported by the histological examinations done in Cases 2 and 8, which confirmed that the dermal collagen showed degeneration, though this may occur in untreated rosacea (Marks, 1968).

The shortest duration of treatment required to produce adverse effects was two months, but in most was six months or more. Only one patient (Case 7) had been given systemic as well as topical steroids, and her response was much the same as in the topical steroid group.

Perhaps the most interesting phenomenon was the rebound inflammation when treatment was stopped. This occurred in 10 of the 14 patients, in the main those who had applied steroids for the longest time. Redness, oedema, and extensive superficial pustulation followed within a week of leaving off the treatment.

In some patients this happened by accident because they had left their ointment at home when they went on holiday, and the inflammation was attributed to sunburn. In Case 4 the relation between rebound pustulation and the cessation of application of fluocinolone ointment was not recognized by me over a number of years. The pustules were smaller but more numerous than those usually seen in rosacea and closely resembled the pustular form of psoriasis. Cases 3 and 4 were so severely affected that hospital admission was required. Usually the rebound reaction settled within three weeks, but was reproduced in one patient (Case 5) by the accidental application of betamethasone ointment for two days, when she had almost recovered.

Patients have been treated with oral tetracycline $250 \mathrm{mg}$. b.d. initially, a month later dropping the dose to $250 \mathrm{mg}$. daily. Tetracycline had been found a reliable method of treatment in a previous trial in rosacea (Sneddon, 1966). Sulphur-containing creams and ung. aquosum were substituted as local treatment for the steroids, but better results were obtained with hydrocortisone ointment, which cut down the violence of the rebound reaction, while allowing the atrophic collagen to recover. The majority of patients have been much improved or completely recovered in three months, and it was surprising how rapidly the telangiectasia faded. This can be seen in the illustrations of Cases 2 and Case 7 (Special Plate). Presumably as the collagen increases in the dermis the plexus of blood vessels becomes invisible.

Though betamethasone figured in nine patients, fluocinolone in four, and fluocortolone 21-hexanoate in one, this probably reflects the pattern of local presoribing, and no conclusion can be drawn from the figures.

This study has thrown no further light on the cause of rosacea or on the mode of action of tetracycline, but I feel the conclusion to be drawn is that the fluorinated topical steroids should not be used in the treatment of rosacea, though the less potent hydrocortisone preparations appear harmless.

I would like to thank my colleague Dr. Ronald Church for permitting me to use details of Case 3, and I am grateful to the department of photography, United Sheffield Hospitals, for the illustrations.

\section{REFERENCES}

Epstein, N. N., Epstein, W. L., and Epstein, J. H. (1963). Archives of

Dermatology, 87, 450.
Grice, K. (for F. R. Bettley) (1966). Proceedings of the Royal Society of Medicine, 59, 254.

Ive, F. A., and Marks, R. (1968). British Medical fournal, 3, 149.

Marks, R. (1968). British fournal of Dermatology, 80, 170.

McKenzie, A. W. (1962). Archives of Dermatology, 86, 611

Sneddon, I. B. (1966). British fournal of Dermatology, 78, 649.

Sneddon, I. B. (1968). British Medical fournal, 1, 579.

\title{
Availability of Food Iron
}

\author{
A. JACOBS,* M.D., M.C.PATH. ; D. A. GREENMAN, $†$ F.I.M.L.T.
}

\begin{abstract}
Summary : Iron has been extracted from 25 common foods under conditions resembling those prevailing in the stomach under physiological conditions. In most cases less than half the iron in the foods is released into solution. The soluble iron is mainly in ionizable form, except in the case of meat products and black pudding. The amount of food iron released is influenced by cooking and the presence of iron-binding substances in some foods. The total dietary iron probably does not represent the amount available for absorption.
\end{abstract}

\section{Introduction}

A considerable body of data exists regarding the iron content of foodstuffs but comparatively little is known about the availability of food iron for absorption in the human small intestine. Early work on iron absorption in which the method of chemical balance was used yielded limited information which does not

* Reader in Haematology.

t. Chief Technician.

Department of Pathology, Welsh National School of Medicine, Cardiff. always agree with later results obtained with tracer doses of radioactive iron (Bothwell and Finch, 1962). Chodos et al. (1957), Moore (1964), and Hussain et al. (1965) obtained direct measurements of iron absorption from a limited number of foods into which radioactive iron had been incorporated during the normal growth process. The investigation of a complete diet by this method would be a formidable procedure. Much detailed information has now accumulated about the absorption of ${ }^{59} \mathrm{Fe}$-labelled inorganic iron and haem iron in man. Many workers have followed the suggestion of Pirzio-Biroli et al. (1958) that a tracer dose of ${ }^{59} \mathrm{Fe}$ added to a test meal will mix with iron released from the food during digestion and thus enable the metabolic progress of food iron to be followed. This is true in a qualitative sense, but a quantitative assessment of food iron absorption by this method can apply only to the specific chemical form of radioactive iron added to the meal and only if the amount of iron released from the food in this form, and thus the total intraluminal pool size, is known.

There is little information about the amount or chemical nature of iron released from food during the digestive process. Shackleton and McCance (1936) estimated the amount of ionizable iron in a large number of foodstuffs, and similar estimates, 
sometimes with different results, have been made by other workers (Ranganathan, 1938). The methods of extraction used in these studies did not always resemble physiological conditions, nor were the methods used for iron estimation as satisfactory as those now available. The present investigation is a preliminary study of the amount of iron released from a number of common foodstuffs by aqueous extraction and by peptic digestion. This represents the amount of iron expected to be present in soluble form in the stomach and therefore available for absorption after these foods are eaten. Ionizable iron and the total amount of soluble iron have been estimated separately. An assessment has been made of the reproducibility of estimates made from different portions of the same food, and in a few cases an attempt has been made to examine the variation between samples of the same food obtained from different sources and the effect of cooking.

\section{Methods}

Fifty-gramme samples of food were homogenized in a Sunbeam blender with $200 \mathrm{ml}$. of iron-free water for four minutes. At the end of this time all samples were reduced to a creamy consistency. An aliquot of the homogenate was incubated at $37^{\circ} \mathrm{C}$. for one and a half hours and then centrifuged at $2,700 \mathrm{~g}$ for 30 minutes. Another aliquot was diluted with an equal volume of $0.5 \%$ pepsin (B.D.H.) in $0.1 \mathrm{~N}$ hydrochloric acid and the $p \mathrm{H}$ adjusted to $1 \cdot 5-2$ with concentrated hydrochloric acid. Incubation was carried out at $37^{\circ} \mathrm{C}$. for one and a half hours before centrifugation. The ionizable iron content of the supernatant solutions was estimated in triplicate by the tripyridyltriazine method of Young and Hicks (1965) and the iron released from the original sample calculated. Total soluble iron was measured after acid-permanganate digestion of triplicate aliquots by the method of Tennant and Greenman (1969). This method measures both ionizable and complexed iron and the total includes soluble iron in the form of ferritin or haem compounds. Duplicate samples of all foods were analysed and in some cases a number of samples of the same food were obtained from different sources for comparison.

The total iron content of each food sample was estimated in triplicate by wet ashing. Five millilitres of an aqueous homogenate and $0.5 \mathrm{ml}$. of concentrated sulphuric acid (B.D.H. Aristar grade) were heated gently in a Kjeldahl flask to boil off excess water. The mixture was heated to $360^{\circ} \mathrm{C}$. in a sand bath with the later addition of $0 \cdot 5-1 \mathrm{ml}$. of sulphuric acid and a few drops of hydrogen peroxide (100 vol. Analar). When digestion was complete $20 \mathrm{ml}$. of iron-free water was added and after boiling the final volume was increased to $50 \mathrm{ml}$. The iron concentration was measured colorimetrically with standards prepared in a 1:100 dilution of concentrated sulphuric acid.

Iron-free water and apparatus were used throughout the investigation. There was no measurable iron contamination from the blender and a pepsin- $\mathrm{HCl}$ blank was included in each analysis. Recovery experiments carried out with acid-permanganate digestion gave the following results: iron salts $100 \%$, haemoglobin iron $97 \%$, ferrioxamine iron $100 \%$, and ferritin iron $104 \%$. Wet ashing gave $100 \%$ recovery of haemoglobin iron.

\section{Results}

An analysis of 84 duplicate portions of individual food items showed very good agreement $(r=0.99)$, so that differences in sampling are not likely to be an important source of variation in the results. The total iron content of 25 common foods is shown in Table I. The values given for meat products, except corned beef and pork pie, are for samples cooked in the hospital kitchen before estimation. Normal kitchen procedure using aluminium vessels was followed. The amount of ionizable iron and total soluble iron released in each case by aqueous extrac- tion and by peptic digestion is also shown. The ionizable iron and the total soluble iron released by peptic digestion is also shown as a percentage of the total iron content of the food. Peptic digestion was generally three to ten times more effective in releasing iron from foods, though it usually liberated less than half the total food iron. The iron in peas, cabbage, and potato chips and crisps was relatively easily released by watery extraction. Most of the soluble iron released by peptic digestion was in ionizable form except in corned beef, beef steak, black pudding, and hard-boiled egg, where a large amount of complexed iron was present. Further analysis of these iron complexes is in progress, and in the case of corned beef, black pudding, and steak a large quantity of haem compounds are undoubtedly present.

TABLE I.-Total Iron Content of 25 Foods and the Amounts Released by Aqueous Extraction and Peptic Digestion. Amount of Ionizable and Total Soluble Iron Released by Peptic Digestion is Also Shown as a Percentage of Total Iron

\begin{tabular}{|c|c|c|c|c|c|}
\hline \multirow[b]{2}{*}{ Food* } & \multirow{2}{*}{$\begin{array}{c}\text { Total } \\
\text { Iron } \\
\text { Content } \\
\text { (mg./ } \\
100 \mathrm{~g} .)\end{array}$} & \multicolumn{2}{|c|}{ Aqueous Extract } & \multicolumn{2}{|c|}{ Peptic Digest } \\
\hline & & $\begin{array}{l}\text { Ioniz- } \\
\text { able } \\
(\mathrm{mg} . / \\
100 \mathrm{~g} .)\end{array}$ & $\begin{array}{c}\text { Total } \\
\text { Soluble } \\
\text { (mg./ } \\
100 \mathrm{~g} .)\end{array}$ & $\begin{array}{c}\text { Ionizable } \\
\text { (mg./100 g.) }\end{array}$ & $\begin{array}{l}\text { Total Soluble } \\
\text { (mg./100 g.) }\end{array}$ \\
\hline $\begin{array}{l}\text { 1. Corned beef (5) } \\
\text { 2. Steamed ham .. } \\
\text { 3. Steakt (6) } . \\
\text { 4. Chicken breast } \dagger \\
\text { 5. Bacont } \\
\text { 6. Pigs'livert } . . \\
\text { 7. Lambs'livert.. } \\
\text { 8. Ox livert } \\
\text { 9. Black puddingt } \\
\text { 10. Faggotst } \\
\text { 11. Sausagest (6) } \\
\text { 12. Steak and kid- }\end{array}$ & $\begin{array}{r}4 \cdot 51 \\
1 \cdot 40 \\
3 \cdot 65 \\
1 \cdot 00 \\
2 \cdot 15 \\
13 \cdot 50 \\
12 \cdot 30 \\
6 \cdot 80 \\
12 \cdot 00 \\
2 \cdot 65 \\
2 \cdot 35\end{array}$ & $\begin{array}{l}0 \cdot 16 \\
0.08 \\
0 \cdot 16 \\
0.06 \\
0 \cdot 14 \\
1.92 \\
1.52 \\
0.96 \\
0.32 \\
0 \cdot 16 \\
0.24\end{array}$ & $\begin{array}{l}0 \cdot 45 \\
0.12 \\
0.30 \\
0.07 \\
0 \cdot 16 \\
3 \cdot 45 \\
2.35 \\
1 \cdot 20 \\
0 \cdot 48 \\
0 \cdot 16 \\
0.29\end{array}$ & $\begin{array}{ll}0.71 & (15.7 \%) \\
0.37 & (26.4 \%) \\
0.62 & (17.0 \%) \\
0.31 & (31.0 \%) \\
0.35 & (16.3 \%) \\
5.80 & (43.0 \%) \\
5.25 & (42.7 \%) \\
2.65 & (39.0 \%) \\
1.75 & (14.6 \%) \\
0.94 & (35.5 \%) \\
0.88 & (37.4 \%)\end{array}$ & $\begin{array}{ll}1.84 & (40.0 \%) \\
0.45 & (32.0 \%) \\
1.73 & (47.5 \%) \\
0.35 & (35.0 \%) \\
0.50 & (23.2 \%) \\
6.55 & (48.5 \%) \\
6.00 & (48.7 \%) \\
3.00 & (44.1 \% \\
4.90 & (40.8 \%) \\
1.02 & (38.5 \%) \\
0.98 & (41.6 \%)\end{array}$ \\
\hline $\begin{array}{l}\text { ney pie } \\
\text { 13. Pork pie }\end{array}$ & $\begin{array}{r}2 \cdot 40 \\
1 \cdot 60 \\
2 \cdot 15 \\
2 \cdot 50 \\
13 \cdot 70\end{array}$ & $\begin{array}{l}0 \cdot 10 \\
0 \cdot 10 \\
0 \cdot 12 \\
0 \cdot 08 \\
0 \cdot 46\end{array}$ & $\begin{array}{l}0 \cdot 10 \\
0 \cdot 16 \\
0 \cdot 14 \\
0.13 \\
0.54\end{array}$ & $\begin{array}{ll}0.80 & (33.3 \%) \\
0.43 & (26.9 \%) \\
0.35 & (16.3 \%) \\
0.60 & (24.0 \%) \\
4.20 & (30.6 \%)\end{array}$ & $\begin{array}{ll}1.06 & (44.2 \%) \\
0.48 & (30.0 \%) \\
0.61 & (27.3 \% \\
0.86 & (34.4 \%) \\
4.10 & (30.0 \%)\end{array}$ \\
\hline $\begin{array}{l}\text { (tinned) } \\
\text { 18. Peas (frozen) } \ldots \\
\text { 19. Cabbage } \\
\text { 20. Potatoes, raw } . \\
\text { 21. Potatoes, chips } \\
\text { 22. Potatoes, crisps } \\
\text { 23. Cheddar cheese } \\
\text { 24. Egg, boiled } \\
\text { 25. Milk, dried }\end{array}$ & $\begin{array}{l}2 \cdot 65 \\
1 \cdot 50 \\
1 \cdot 10 \\
0.50 \\
1 \cdot 25 \\
1.80 \\
1.10 \\
2 \cdot 35 \\
0.90\end{array}$ & $\begin{array}{l}0.06 \\
0.28 \\
0.08 \\
0.06 \\
0.84 \\
0.52 \\
0.10 \\
0.06 \\
-\end{array}$ & $\begin{array}{l}0.18 \\
0.59 \\
0.14 \\
0.10 \\
0.86 \\
0.64 \\
0.10 \\
0.14\end{array}$ & $\begin{array}{ll}0.88 & (33.2 \%) \\
0.53 & (35.4 \%) \\
0.14 & (12.8 \%) \\
0.31 & (62.0 \%) \\
0.85 & (68.0 \%) \\
0.70 & (38.9 \%) \\
0.21 & (19.1 \%) \\
0.35 & (14.9 \%) \\
0.14 & (15.5 \%)\end{array}$ & $\begin{array}{ll}1.55 & (58.5 \%) \\
0.62 & (41.3 \%) \\
0.26 & (23.6 \%) \\
0.35 & (70.0 \%) \\
0.88 & (70.5 \% \%) \\
0.82 & (45.6 \% \\
0.26 & (23.6 \%) \\
0.78 & (33.2 \%) \\
0.16 & (17.8 \%)\end{array}$ \\
\hline
\end{tabular}

* Number in parentheses indicates number of food samples.

t Cooked

The effect of cooking on the total iron content and its availability were investigated in the eight foods shown in Table II. The meat samples were divided into equal parts, one of which was fried in an aluminium pan under normal kitchen conditions. Eggs were taken from the same batch and half, selected randomly, were hard-boiled. There was an increase in total iron concentration after cooking in all the meats except ox liver and black pudding, and in no case was there a significant decrease after cooking. The apparent increase in iron was probably due to loss of water and fat during the cooking pro-

TABLE II.-Effect of Cooking on Total Iron Content and Release of Iron From Eight Foods. Values Expressed as mg./100 g. Samples

\begin{tabular}{|c|c|c|c|c|c|c|c|c|}
\hline \multirow{2}{*}{\multicolumn{3}{|c|}{ Food* }} & \multirow{3}{*}{ 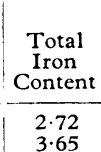 } & \multicolumn{2}{|c|}{ Aqueous Extract } & \multicolumn{3}{|c|}{ Peptic Digest } \\
\hline & & & & \multirow{2}{*}{$\begin{array}{c}\begin{array}{c}\text { Ioniz- } \\
\text { able }\end{array} \\
\begin{array}{l}0.12 \\
0.16\end{array}\end{array}$} & \multirow{2}{*}{\begin{tabular}{|c|c|}
$\begin{array}{c}\text { Total } \\
\text { Soluble }\end{array}$ \\
1.59 \\
0.30
\end{tabular}} & \multirow{2}{*}{$\begin{array}{c}\begin{array}{c}\text { Ioniz- } \\
\text { able }\end{array} \\
0.30 \\
0.62\end{array}$} & \multicolumn{2}{|c|}{$\begin{array}{c}\text { Total } \\
\text { Soluble }\end{array}$} \\
\hline Steak (6) & . & $\begin{array}{l}a \\
b\end{array}$ & & & & & $\begin{array}{l}1.69 \\
1.73\end{array}$ & $\begin{array}{l}\left(62 \cdot 0^{\circ}\right) \\
\left(47 \cdot 5{ }^{\circ}\right)\end{array}$ \\
\hline & & a & 1.35 & $0 \cdot 10$ & 0.36 & 0.23 & 0.50 & $(37.0 \%)$ \\
\hline Bacon & . & $\mathrm{b}$ & $2 \cdot 15$ & $0 \cdot 14$ & 0.16 & 0.35 & 0.50 & $\left(23.2^{\circ} \circ\right)$ \\
\hline Pigs' liver .. & & a & $\begin{array}{r}9 \cdot 50 \\
13.50\end{array}$ & $2 \cdot 20$ & $\begin{array}{l}5 \cdot 30 \\
3.45\end{array}$ & $\begin{array}{l}3 \cdot 85 \\
5 \cdot 80\end{array}$ & $\begin{array}{l}3.90 \\
6.55\end{array}$ & $\left(41 \cdot 0^{\circ}{ }^{\circ}\right)$ \\
\hline & & a & $\begin{array}{r}13 \cdot 50 \\
8 \cdot 40\end{array}$ & $\begin{array}{l}1 \cdot 92 \\
1 \cdot 12\end{array}$ & $\begin{array}{l}3.43 \\
5.85\end{array}$ & 2.35 & $4 \cdot 85$ & $(57.8 \%)$ \\
\hline Lambs'liver & & & $12 \cdot 30$ & 1.52 & $2 \cdot 35$ & 5.25 & $6 \cdot 00$ & $(48.7 \%)$ \\
\hline Ox liver & & a & $\begin{array}{l}6 \cdot 30 \\
6 \cdot 80\end{array}$ & $\begin{array}{l}1.12 \\
0.96\end{array}$ & $\begin{array}{l}3 \cdot 70 \\
1 \cdot 20\end{array}$ & $\begin{array}{l}1.92 \\
2.65\end{array}$ & $\begin{array}{l}2.05 \\
3.00\end{array}$ & $\begin{array}{l}\left(32 \cdot 6^{\circ}\right) \\
(44 \cdot 1\end{array}$ \\
\hline & & $\therefore \mathrm{a}$ & $12 \cdot 00$ & $0 \cdot 14$ & 0.28 & 0.98 & $2 \cdot 25$ & $(18 \cdot 7 \%)$ \\
\hline Black puddin & & $i b$ & $12 \cdot 00$ & 0.32 & 0.48 & 1.75 & $4 \cdot 90$ & $\left.\left(40 \cdot 8^{\circ}\right)^{\circ}\right)$ \\
\hline Sausages (6) & & $\begin{array}{l}a \\
b\end{array}$ & $\begin{array}{l}1 \cdot 59 \\
2 \cdot 35\end{array}$ & $\begin{array}{l}0 \cdot 24 \\
0.24\end{array}$ & $\begin{array}{l}0.49 \\
0.29\end{array}$ & $\begin{array}{l}0 \cdot 27 \\
0 \cdot 88\end{array}$ & $\begin{array}{l}\mathbf{0 . 4 5} \\
0.98\end{array}$ & $\begin{array}{l}\left(28.3^{\circ}\right) \\
\left(41.6^{\circ}\right)\end{array}$ \\
\hline Egg & . & a & $\begin{array}{l}2 \cdot 40 \\
2 \cdot 35\end{array}$ & $\begin{array}{l}0.70 \\
0.06\end{array}$ & $\begin{array}{l}0.67 \\
0.14\end{array}$ & $\begin{array}{l}0.80 \\
0.35\end{array}$ & $\begin{array}{l}1.56 \\
0.78\end{array}$ & $\begin{array}{l}(65.0 \% \\
(33.2 \%)\end{array}$ \\
\hline
\end{tabular}

$=$ Raw. $b=$ Cooked

Number in parentheses indicates number of food samples.

t Hard-boiled. 
cess rather than to contamination from utensils. There was no significant difference in the iron content of raw and hard-boiled egg. After cooking the total amount of soluble iron released by peptic digestion was increased in five of the seven meats tested, but aqueous extraction was often less effective. Boiled egg showed a striking reduction in the total iron released compared with raw egg. In raw liver and sausages peptic digestion is less effective in releasing iron than aqueous extraction. Samples of beef steak, corned beef, and sausages obtained from different sources were compared (Table III). The most striking differences in iron content were found in the case of corned beef, but it is apparent that some variation must be assumed in all foods.

TABLE III.-Total Iron Content of Different Samples of Sirloin Steak, Sausages, and Corned Beef. Values Expressed as mg./100 g. Sample

\begin{tabular}{c|c|c|c|c|c}
\hline \multirow{2}{*}{ Sample } & \multicolumn{2}{|c|}{ Steak } & \multicolumn{2}{|c|}{ Sausages } & \multirow{2}{*}{ Corned Beef } \\
\cline { 2 - 5 } & Raw & Cooked & Raw & Cooked & \\
\hline 1 & 3.25 & 3.65 & 1.50 & 2.00 & 9.00 \\
2 & 3.25 & 3.25 & 1.25 & 2.00 & 4.40 \\
3 & 3.15 & 4.65 & 1.90 & 2.40 & 3.50 \\
4 & 2.55 & 3.75 & 1.90 & 3.90 & 2.50 \\
5 & 2.10 & 2.90 & 1.40 & 1.40 & 3.15 \\
6 & 2.30 & 3.70 & 1.60 & 2.40 & - \\
\hline Mean & 2.72 & 3.65 & 1.59 & 2.35 & 4.51 \\
\hline
\end{tabular}

One of the factors affecting the release of ionizable iron from foodstuffs is the presence of binding substances in the foods. Some interaction may also be expected between binding substances in food with iron released from other foods. The recovery of ionic iron in the form of ferric nitrate added to the peptic digests of five foods is shown in Table IV. White bread and egg are especially able to reduce the availability of ferric iron.

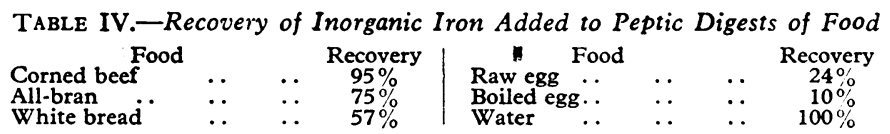

\section{Discussion}

The total iron content of all foods was determined after wet ashing, and though the results were of the expected order exact agreement with published data was not found (Table V). Correlation between our results and the corresponding figures in the

TABLE V.- Iron Content of Foods Determined in This Study Compared With Values Taken from the Tables of McCance and Widdowson (1967) and Watt and Merrill (1963)

\begin{tabular}{|c|c|c|c|c|c|c|}
\hline \multirow{2}{*}{\multicolumn{2}{|c|}{ Food* }} & & & \multicolumn{3}{|c|}{ Total Iron Content (mg./100 g.) } \\
\hline & & & & $\begin{array}{c}\text { Direct } \\
\text { Estimation }\end{array}$ & $\begin{array}{c}\text { McCance } \\
\text { and } \\
\text { Widdowson }\end{array}$ & $\begin{array}{l}\text { Watt and } \\
\text { Merrill }\end{array}$ \\
\hline $\begin{array}{l}\text { 1. Corned beef (5) } \\
\text { 2. Steamed ham } \\
\text { 3. Steakt }(6) . . \\
\text { 4. Chicken breast } \dagger \\
\text { 5. Bacont } \\
\text { 6. Pigs' livert .. } \\
\text { 7. Lambs' livert } \\
\text { 8. Ox livert } \ldots \\
\text { 9. Black puddingt } \\
\text { 10. Faggots } \dagger \\
\text { 11. Sausages }(6) \\
\text { 12. Steak and kidney p } \\
\text { 13. Pork pie } \\
\text { 14. White bread } \\
\text { 15. Brown bread } \\
\text { 16. All-bran } \\
\text { 17. Pilchards (tinned) } \\
\text { 18. Peas (frozen) } \\
\text { 19. Cabbage } \ldots \\
\text { 20. Potatoes, raw } \\
\text { 21. Potatoes, chips } \\
\text { 22. Potatoes, crisps } \\
\text { 23. Cheddar cheese } \\
\text { 24. Egg, boiled .. } \\
\text { 25. Milk, dried .. }\end{array}$ & 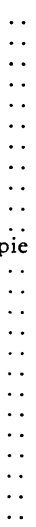 & $\begin{array}{l}\cdots \\
\cdots \\
\cdots \\
\cdots \\
\cdots \\
\cdots \\
\cdots \\
\cdots \\
\cdots \\
\cdots \\
\cdots \\
\cdots \\
\cdots \\
\cdots \\
\cdots \\
\cdots \\
\cdots\end{array}$ & $\begin{array}{l}\cdots \\
\cdots \\
\cdots \\
\cdots \\
\cdots \\
\because \\
\cdots \\
\cdots \\
\because \\
\because \\
\because \\
\cdots \\
\because \\
\because \\
\therefore \\
\cdots \\
\cdots \\
\cdots\end{array}$ & $\begin{array}{r}4 \cdot 51 \\
1 \cdot 40 \\
3 \cdot 65 \\
1 \cdot 00 \\
2 \cdot 15 \\
13 \cdot 50 \\
12 \cdot 30 \\
6 \cdot 80 \\
12 \cdot 00 \\
2 \cdot 65 \\
2 \cdot 35 \\
2 \cdot 40 \\
1 \cdot 60 \\
2 \cdot 15 \\
2 \cdot 50 \\
13 \cdot 70 \\
2 \cdot 65 \\
1.50 \\
1 \cdot 10 \\
0.50 \\
1 \cdot 25 \\
1.80 \\
1 \cdot 10 \\
2.35 \\
0.90\end{array}$ & 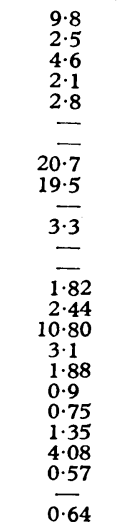 & $\begin{array}{r}4.3 \\
3.1 \\
1.7 \\
3.3 \\
29.1 \\
17.9 \\
8.8 \\
\overline{-} \\
2.4 \\
- \\
2.4 \\
2.3 \\
- \\
1.9 \\
0.4 \\
0.6 \\
1.3 \\
1.8 \\
1.0 \\
2.3 \\
0.5\end{array}$ \\
\hline
\end{tabular}

* Number in parentheses indicates number of food samples.
+ Cooked. tables published by McCance and Widdowson (1967) was not as high $(r=0.81)$ as that obtained with figures taken from Watt and Merrill's (1963) tables $(r=0.96)$. On average our results were $16 \%$ lower than those of McCance and Widdowson and $6 \%$ lower than those of Watt and Merrill. Previous comparisons of the iron content of whole diets determined by analysis and by calculation from food tables have not generally shown good agreement, chemical analysis giving higher results (Leverton, 1937 ; Bransby et al., 1948). However, Monsen et al. (1967) obtained good agreement between analysis and the figures given by Watt and Merrill.

It is known that individual food items may vary considerably in their composition because of differences in production, storage, and preparation for consumption. Apparently similar foods purchased in different shops may vary considerably in composition (Table III). In addition to these factors there is of ten a difficulty in defining particular food items, which may partly explain the differences in iron content between the two reference Tables. A comparison of the two Tables for the foods shown in Table $\mathrm{V}$ gives a correlation coefficient of 0.96 . A more detailed comparison of iron values for 46 foods comprising the major iron sources of the British diet gives a correlation coefficient of $0.92 ; y$ (Watt and Merrill) $=0.71 \times($ McCance and Widdowson $)+0 \cdot 33$. While overall correlation of the actual iron content of a mixture of foods and the calculated content may often be good, the variation between individual items makes chemical analysis essential where specific data are required, as in the present study.

The availability of food iron for absorption depends on a number of variables besides its chemical nature in the natural state. Physical factors determining the ease with which the food is masticated and digested play a part in the release of tissue iron compounds, and the presence of iron-binding substances in food may increase or decrease its availability. Phosphate or phytate may precipitate ionic iron from solution and reducing compounds may be important in maintaining the relatively soluble ferrous form. The initial breakdown and digestion of food in the stomach normally extends over one to two hours, and it is here that the release of iron and its interaction with gastric juice and other food components largely occurs (Conrad, 1968). We have replaced the normal process of mastication by thorough homogenization and then subjected the homogenate to peptic digestion in vitro for one and a half hours at body temperature and determined the amount of iron released. In each case an aliquot of homogenate has been extracted with water for the same time, and the release of iron in the absence of peptic activity has been measured.

In several older studies the availability of food iron when determined chemically has usually related to ionizable iron only and the methods of extraction have not always been physiological. Raw foods were heated to $100^{\circ} \mathrm{C}$. for 10 minutes as part of the extraction process used by Shackleton and McCance (1936), while Sherman et al. (1934) boiled their samples with $5 \mathrm{~N} \mathrm{HC1}$ for 10 minutes. These workers found a larger proportion of total food iron to be released in ionizable form than was the case in the present study, and in the latter report $10 \%$ of the total iron in blood was said to be available in this form. More recently Sanford (1960) estimated ionized iron liberated from foodstuffs by saline extraction and peptic digestion. In the case of cooked liver $2.6 \%$ and $51.6 \%$ of the total iron was released as ionic iron by these procedures compared with 12.3 to $14.2 \%$ and 39.0 to $43.0 \%$ in the present study.

The total soluble iron estimated by acid-permanganate digestion includes ionizable iron, haem iron, ferritin, and iron bound in other soluble complexes. The precise constitution of the non-ionizable fraction is being studied further and it can be expected to vary considerably between different foodstuffs. In the case of red meat a large part of this is probably haem iron. Only $18 \%$ of the soluble iron released from raw steak and $36 \%$ of the iron released from fried steak is in ionizable form. In the case of fried liver, where a large amount of the iron is present 
as ferritin or haemosiderin, peptic digestion releases nearly all the iron in an ionizable form. Free iron released from food may form soluble complexes with ligands in the gastrointestinal lumen or may be precipitated in insoluble form. The factors governing its absorption have been extensively studied by radioisotope techniques (Callender, 1967). The absorption of haem iron has also been studied (Conrad et al., 1967) but little is known regarding other food complexes.

The present data indicate that only part of the iron present in food is likely to be liberated in the stomach and that in most instances only a fraction of this is in ionic form. The proportion released is between 17 and $70 \%$ for different foods, though most release about 30 to $50 \%$. It is possible that further release takes place in the upper small intestine, but in this situation ionic iron would be rapidly converted to an insoluble form. Subjects with achlorhydria are likely to have less iron released from food. The absorption of ionic iron is reduced by the presence of food, and certain foods are known to have a special inhibitory effect. The presence of iron-binding substances in bread and egg is shown in Table IV, and an interaction of this kind between mixtures of foods in the stomach is to be expected. The difference in iron availability for each food has already been shown by labelling experiments (Moore, 1964), and this appears to be due to the amount which is rendered soluble as well as its chemical nature.

It is estimated that iron absorption from a normal diet is about $10 \%$ in healthy subjects (Moore, 1964), but if availability is incomplete then absorption from the soluble iron pool in the gut lumen must be greater than this. While the body requirements for iron may be calculated from the amounts known to be lost (Green et al., 1968) it becomes difficult to calculate the amount of dietary iron needed to fulfil them while availability remains unknown.

This work was supported by a grant from the Endowment Fund of the United Cardiff Hospitals.

\section{REFERENCES}

Bothwell, T. H., and Finch, C. A. (1962). Iron Metabolism. London. Bransby, E. R., Daubney, C. G., and King, J. (1948). Brit. f. Nutr., 2, 232

Callender, S. T. (1967). Brit. med. Bull., 23, 263.

Chodos, R. B., Ross, J. F., Apt, L., Pollycove, M., and Halkett, J. A. E. (1957). f. clin. Invest., 36, 314.

Conrad, M. E. (1968). Israel f. med. Sci., 4, 917

Conrad, M. E., Benjamin, B. I., Williams, H. L., and Foy, A. L. (1967). Gastroenterology, 53, 5.

Green, R., et al. (1968). Amer. F. Med., 45, 336

Green, R., et al. (1968). Amer. F. Med., 45, 336. . (1965). Amer. \%. clin. Nutr., 16, 464.

Leverton, R. M. (1937). f. Amer. diet. Ass., 13, 139.

McCance, R. A., and Widdowson, E. M. (1967). Spec. Rep. Ser. med. Res. Coun. (Lond.), No. 297 (new edition).

Monsen, E. R., Kuhn, I. N., and Finch, C. A. (1967). Amer. F. clin. Nutr., 20, 842 .

Moore, C. V. (1964). In Iron Metabolism-An International Symposium edited by F. Gross. Berlin.

Pirzio-Biroli, G., Bothwell, T. H., and Finch, C. A. (1958). F. Lab. clin. Med., 51, 37.

Ranganathan, S. (1938). Indian 7. med. Res., 26, 119.

Ranganathan, S. (1938). Indian f. med. Res.,

Shackleton, L., and McCance, R. A. (1936). Biochem. F., 30, 582

Shackleton, L., and McCance, R. A. (1936). Biochem. f., 30, 582 . 107, 383

Tennant, G. B., and Greenman, D. A. (1969). 7. clin. Path. In press.

Watt, B. K., and Merrill, A. L. (1963). "Composition of Foods." Agricultural Handbook No. 8. U.S. Department of Agriculture, Washington.

Young, D. S., and Hicks, Jocelyn M. (1965). F. clin. Path., 18, 98.

\title{
Plasma Insulin during Remission in Juvenile Diabetes Mellitus
}

\author{
K. JOHANSEN,* M.D. ; H. ØRSKOV,† M.D.
}

Brit. med.F., 1969, 1, 676-678

\begin{abstract}
Summary : Three juvenile diabetics in partial remission $\checkmark$ were studied before and after the recurrence of overt diabetes. The remissions were partial because glucose tolerance never returned to normal. However, it improved sufficiently to cause the discontinuance of insulin therapy for at least four months.

The insulin output in response to double glucose tolerance tests was increased during remission. The degree of remission seemed to be related to the magnitude of the insulin response to glucose. In two of the patients the increase was low and the response very slight. The third patient, however, had a delayed hyper-response and his carbohydrate tolerance during the remission was much more improved than those of the other patients.
\end{abstract}

\section{Introduction}

It is generally accepted that a remission occasionally occurs in the initial stage of diabetes in young people and children. The term has been used to designate anything from the doubtfully

\footnotetext{
* Kandidatstipendiat.

Second University Clinic of Internal Medicine, Kommunehospitalet, Aarhus, Denmark.
}

significant improvement which occurs during the early treatment of ketotic juvenile diabetics when insulin requirements are decreasing to those cases where pronounced and sometimes dramatic improvement necessitates discontinuance of insulin treatment. In exceptional cases patients have tolerated high carbohydrate diet for a long time and even had normal glucose tolerance tests for a period (Carlström and Ingemanson, 1967). Only these latter cases should be termed "complete remissions." Almost invariably, however, typical juvenile diabetes recurs after an interval of weeks or months. A period of improved carbohydrate tolerance in patients with maturityonset diabetes is often referred to as a remission. The mild diabetic state typical of this condition in patients who generally have large pancreatic insulin reserves is easily influenced by exogenous factors such as slight infection, alterations in body weight, or, perhaps most important, changes in dietary habits. The rarely occurring remissions in the severely diabetic juvenile patients who cannot raise their plasma insulin during the overt stage of diabetes is far more difficult to understand.

The endocrinological basis for this alteration in metabolism is still an intriguing enigma. The few reports of studies which include immunological hormone analysis differed with respect to the completeness of the remissions investigated and therefore in their results and conclusions (Grodsky et al., 1965 ; Baker et al., 1967 ; Hernandez et al., 1968). For these reasons we 